\title{
Control of Biological Exposure to UV Radiation in the Arctic Ocean: Comparison of the Roles of Ozone and Riverine Dissolved Organic Matter
}

\author{
JOHN A.E. GIBSON, ${ }^{1}$ WARWICK F. VINCENT, ${ }^{1,2}$ BARBARA NIEKE ${ }^{3}$ and REINHARD PIENITZ ${ }^{4}$
}

(Received 20 November 1998; accepted in revised form 7 July 1999)

\begin{abstract}
Reports of severe stratospheric ozone depletion over the Arctic have heightened concern about the potential impact of rising ultraviolet-B (UV-B) radiation on north polar aquatic ecosystems. Our optical measurements and modelling results indicate that the ozone-related UV-B influence on food web processes in the Arctic Ocean is likely to be small relative to the effects caused by variation in the concentrations of natural UV-absorbing compounds, known as chromophoric dissolved organic matter (CDOM), that enter the Arctic basin via its large river inflows. The aim of our present study was to develop and apply a simple bio-optical index that takes into account the combined effects of attenuation by atmospheric ozone and water column CDOM, and photobiological weighting for high-latitude environments such as the Arctic Ocean. To this end, we computed values for a biologically effective UV dose rate parameter ("weighted transparency" or T*) based on underwater UV measurements in highlatitude lakes and rivers that discharge into the Arctic Ocean; measured incident UV radiation at Barrow, Alaska; and published biological weighting curves for UV-induced DNA damage and UV photoinhibition of photosynthesis. The results underscore how strongly the Arctic Ocean is influenced by riverine inputs: shifts in CDOM loading (e.g., through climate change, land-use practices, or changes in ocean circulation) can cause variations in biological UV exposure of much greater magnitude than ozonerelated effects.
\end{abstract}

Key words: Arctic, CDOM, DNA, global change, ozone depletion, phytoplankton, Siberia, transparency, ultraviolet radiation

RÉSUMÉ. Des rapports concernant un appauvrissement sérieux de l'ozone stratosphérique au-dessus de l'Arctique ont accru les préoccupations au sujet de l'impact potentiel d'un plus fort rayonnement ultraviolet-B (UV-B) sur les écosystèmes aquatiques du pôle Nord. Nos mesures optiques et nos résultats de modélisation indiquent que l'influence de l'UV-B relié à la couche d'ozone sur les processus du réseau trophique dans l'océan Arctique est probablement faible en comparaison avec les effets dus à la variation dans les concentrations des composés absorbants naturels de l'UV, connus sous le nom de matière organique dissoute chromophore, qui entrent dans le bassin Arctique par le biais de l'eau amenée par les cours d'eau majeurs. Le but de la présente étude était de développer et d'appliquer un index bio-optique simple qui tient compte des effets combinés de l'atténuation due à l'ozone atmosphérique et à la matière organique dissoute chromophore dans la colonne d'eau, et de la pondération photobiologique pour les écosystèmes des hautes latitudes comme l'océan Arctique. À cette fin, nous avons calculé les valeurs pour un paramètre de débit de dose UV qui ait une action biologique («transparence pondérée» ou $T^{*}$ ) fondée sur des mesures sous l'eau du rayonnement UV dans des lacs et cours d'eau de hautes latitudes qui se déversent dans l'océan Arctique; sur des mesures du rayonnement UV incident à Barrow, en Alaska; et sur des courbes de pondération biologique élaborées pour le dommage à l'ADN provoqué par le rayonnement UV et la photoinhibition UV de la photosynthèse. Les résultats font ressortir l'importance de l'influence sur l'océan Arctique des apports fluviaux: des modifications dans la charge de matière organique dissoute chromophore (p. ex., dues au changement climatique, aux pratiques d'utilisation des terres ou aux changements dans la circulation océanique) peuvent causer des variations dans l'exposition biologique aux UV, qui sont d'une importance beaucoup plus grande que les répercussions reliées à l'ozone.

Mots clés: Arctique, matière organique dissoute chromophore, ADN, changement à l'échelle planétaire, phytoplancton, Sibérie, transparence, rayonnement ultraviolet

Traduit pour la revue Arctic par Nésida Loyer.

\footnotetext{
${ }^{1}$ Centre d'Études Nordiques, Université Laval, Sainte-Foy, Québec G1K 7P4, Canada

${ }^{2}$ Corresponding author: Département de biologie, UniversitéLaval, Sainte-Foy, Quebec G1K 7P4, Canada; warwick.vincent@ bio.ulaval.ca

${ }^{3}$ Department of Oceanography, Dalhousie University, Halifax, Nova Scotia B3H 4J1, Canada

${ }^{4}$ Centre d'Études Nordiques, Université Laval, Sainte-Foy, Québec G1K 7P4, Canada

(C) The Arctic Institute of North America
} 


\section{INTRODUCTION}

Substantial ozone depletion has been recorded in recent winters over the Arctic (Fioletov et al., 1997; Knudsen et al., 1998; Wessel et al., 1998), and Rex et al. (1997:835) warned that "more dramatic ozone losses may occur in the future." The International Arctic Science Committee (1995) raised concern that the increase in ultraviolet (UV) radiation resulting from ozone depletion could have severe negative impacts on primary production and other food web processes in the Arctic Ocean. Increased UV radiation has numerous detrimental effects on phytoplankton and other microbial organisms, including DNA damage and impairment of many physiological processes, such as algal photosynthesis (Karentz et al., 1994; Vincent and Neale, 2000). Such changes would also affect grazers that rely on the phytoplankton and could ultimately affect the entire marine ecosystem (Hessen et al., 1997).

The magnitude of the biological effects of UV radiation per unit energy flux rises sharply with decreasing wavelength across the UV-A (320-400 nm) and UV-B (290$320 \mathrm{~nm}$ ) wavebands. UV exposure is typically described in terms of a biologically effective dose rate, in which the radiation flux at each wavelength $\left(E_{\lambda}\right)$ is multiplied by a weighting factor of the relative biological effect at that wavelength $\left(\varepsilon_{\lambda}\right)$ (Smith and Baker, 1979). In the natural aquatic environment, the effect of greatest photobiological damage at the shortest wavelength is offset by two factors causing UV attenuation: the ozone column of the atmosphere and the chromophoric (i.e., coloured) dissolved organic matter (CDOM) in the water column.

Although many authors have speculated on the UVprotective role of CDOM, few studies have attempted to quantify this effect relative to the increased incident UV at the earth's surface resulting from reduced stratospheric ozone concentrations. The detailed modelling study by Arrigo and Brown (1996), using data from the Southern Ocean, indicated that the concentration of CDOM is important in controlling UV penetration, and that the negative effects of reduced productivity resulting from a decrease in photosynthetically active radiation are generally outweighed by the positive effects resulting from the reduction of UV penetration. The aim of our present study was to develop and apply a simple bio-optical parameter that takes into account the combined effects of attenuation by atmospheric ozone and by water column CDOM and photobiological weighting for high-latitude environments such as the Arctic Ocean. The index of underwater UV exposure provides an approach towards comparing the effects of ozone depletion and changes in CDOM on a common, biologically relevant scale.

CDOM largely results from the microbial and enzymatic breakdown of terrestrial organic matter (especially ligninbased structural tissues of plants) into smaller molecules, such as humic and fulvic acids, that are more resistant to further decomposition. The majority of the terrestrially derived dissolved organic carbon (DOC) reaching the

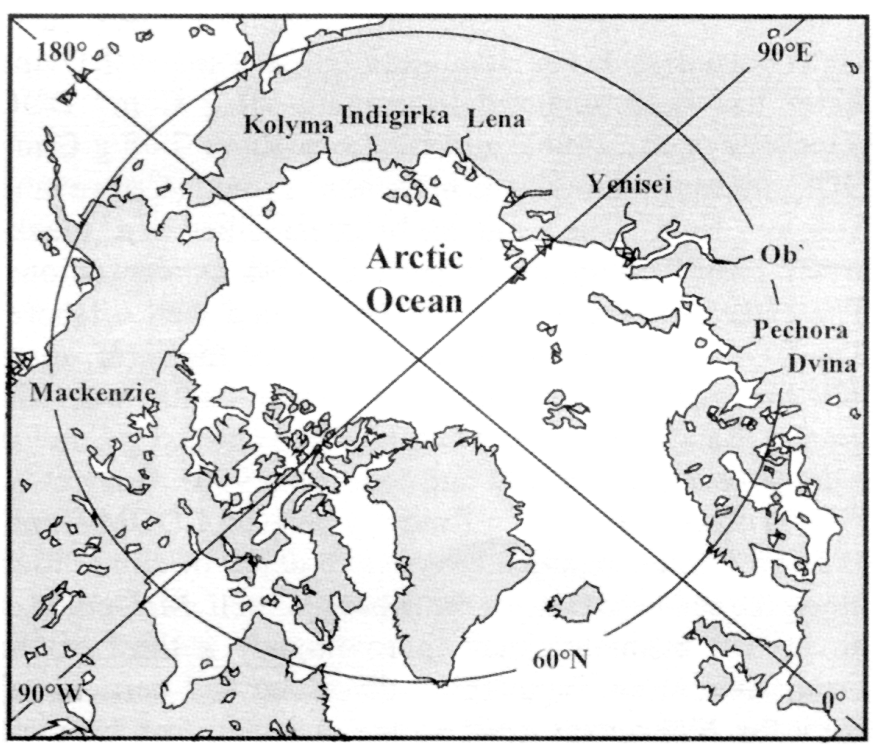

FIG. 1. Map of the north polar region showing the locations of the major river inputs into the Arctic Ocean.

ocean is of this type, as more labile molecules have already been substantially removed by bacterial and chemical processes. CDOM is characterized by an exponential increase in absorbance with decreasing wavelength over the visible, UV-A, and UV-B ranges (Kirk, 1994). As a result of these characteristics, CDOM can modify the optical properties of aquatic systems substantially through its effect on the underwater spectral regime (Blough et al., 1993), protecting organisms in both limnetic and marine systems from exposure to damaging UV radiation (Scully and Lean, 1994; Arrigo and Brown, 1996; Williamson et al., 1996; Laurion et al., 1997).

The Arctic Ocean is strongly influenced by the inflow of many high-order rivers, including the Kolyma, Indigirka, Lena, Yenesei, Ob', Pechora, Dvina, and Mackenzie systems (Fig. 1), which deliver large amounts of freshwater and CDOM derived from catchment soils and vegetation to the marine environment (Cauwet and Sidorov, 1996). These rivers drain over $15 \times 10^{7} \mathrm{~km}^{2}$ of the forests and tundra of the North American and Eurasian land masses (Gordeev et al., 1996; Cauwet and Sidorov, 1996; Olsson and Anderson, 1997), and their annual flow to the ocean is estimated to exceed $3500 \mathrm{~km}^{3}$. The outflow plumes from the rivers reach well into the ocean (Cauwet and Sidorov, 1996; Dickson, 1999), resulting in a freshwater surface layer and a sharp halocline at 30 to $60 \mathrm{~m}$ that have a strong influence on ocean mixing and ice formation (Cattle, 1985; Aagaard and Carmack, 1989; Steele et al., 1996). Other important riverine inputs to the Arctic Ocean include heat (Cattle, 1985) and nutrients (Gordeev et al., 1996), as well as anthropogenic pollutants (Yunker and Macdonald, 1995; Naidu et al., 1997; Zegouagh et al., 1998). The average half-life of freshwater in the Arctic Ocean surface layer above the halocline is $10-15$ years, but it is much shorter over the Siberian Shelf, where the majority of the freshwater input occurs (Schlosser et al., 1994; Bauch et al., 1995). 
Many of the rivers, especially those in Siberia, carry high concentrations of DOC and CDOM. The North Dvina River has been reported to contain $20 \mathrm{~g} \mathrm{C} \mathrm{m}^{-3}$ DOC (Gordeev et al., 1996), and the Lena River 7-8 $\mathrm{g} \mathrm{C} \mathrm{m}^{-3}$ DOC, increasing to $12 \mathrm{~g} \mathrm{C} \mathrm{m}^{-3}$ when in flood (Cauwet and Sidorov, 1996). The Lena has been described as a "blackwater river" implying elevated CDOM concentrations. The effects of these river inflows extend well offshore. The DOC concentration near the edge of the shelf, some $400 \mathrm{~km}$ offshore from the Lena River Delta, was still greater than $5 \mathrm{~g} \mathrm{C} \mathrm{m}^{-3}$ at a depth of $4 \mathrm{~m}^{2}$ and $2.5 \mathrm{~g} \mathrm{C} \mathrm{m}^{-3}$ at a depth of $35 \mathrm{~m}$ (Cauwet and Sidorov, 1996). Guay et al. (1999) observed a strong fluvially derived CDOM signal (12-56\% total organic carbon) at a depth of circa $50 \mathrm{~m}$ along the seaward edge of the Siberian Shelf. McDonald et al. (1998) estimated that approximately a third of the terrestrial carbon input (both dissolved and particulate) from the Mackenzie River to the Beaufort Sea survived sedimentation and oxidation/regeneration processes within the delta and shelf systems and was exported to the open ocean. In contrast, $97 \%$ of the marine primary production that occurred over the shelf was remineralized, and therefore the vast majority of the carbon exported from the shelf area was DOC from terrestrial sources. Finally, Wheeler et al. (1997) estimated that $25 \%$ of the DOC present in the central Arctic Basin, far distant from the inputs, was derived from riverine sources.

\section{BACKGROUND TO THE MODEL}

The biologically effective dose rate $\left(\mathrm{E}^{*}{ }_{\lambda} ; *\right.$ indicates that the parameter is biologically weighted) for irradiance $E$ at wavelength $\lambda$ is defined as:

$$
\mathrm{E}_{\lambda}^{*}=\mathrm{E}_{\lambda} \varepsilon_{\lambda}
$$

where $\varepsilon_{\lambda}$ is a biological weighting factor that expresses the relative damaging effect of the radiation at $\lambda$. The flux of $\mathrm{UV}$ radiation at wavelength $\lambda$ and depth $\mathrm{z}$ in a water body, $\mathrm{E}_{\lambda z}$, is calculated by:

$$
\mathrm{E}_{\lambda \mathrm{z}}=\mathrm{E}_{\lambda}^{0} \mathrm{~F}_{\lambda \omega} \mathrm{e}^{\left(-K_{\mathrm{d} \lambda} \mathrm{z}\right)}
$$

where $E_{\lambda}^{0}$ is the radiative flux immediately beneath the surface of the water at wavelength $\lambda$ under 'normal' ozone conditions (here defined as 330 Dobson Units (DU)), and $K_{\mathrm{d} \lambda}$ is the diffuse attenuation coefficient at the same wavelength. $E_{\lambda}^{0}$ is in turn a function of the solar radiation impinging on the top of the atmosphere (which is a function of latitude, time of day, and date), scattering and absorption within the atmosphere by aerosols and chemical species other than ozone, and radiative losses resulting from reflection and other processes occurring at the airwater interface (Green et al., 1974). $F_{\lambda \omega}$ is the enhancement factor for radiation of wavelength $\lambda$ resulting from a decrease in ozone concentration from 330 to $\omega \mathrm{DU}$. This factor has a value of 1.0 at an ozone concentration of 330 DU, and increases as ozone concentration decreases.

The biologically effective dose rate at this wavelength and depth $\left(\mathrm{E}^{*} \lambda_{z}\right)$ is determined by multiplying the radiative flux by the biological weighting function $\varepsilon_{\lambda}$ (Smith and Baker, 1979):

$$
\mathrm{E}^{*}{ }_{\lambda \mathrm{z}}=\mathrm{E}_{\lambda}^{0} \mathrm{~F}_{\lambda \omega} \varepsilon_{\lambda} \mathrm{e}^{\left(-K_{\mathrm{d} \lambda} \mathrm{z}\right)}
$$

$\mathrm{E}^{*}{ }_{\lambda z}$ will decrease with increasing depth in the water column as UV radiation is absorbed by dissolved and particulate matter, as well as by the water itself. The total biologically effective dose rate for a particular wavelength within the water column $\left(\mathrm{E}^{*}{ }_{\lambda}\right)$ can be calculated by integrating from the surface to the maximum depth of the water column or of the mixed layer, $\mathrm{z}_{\mathrm{m}}$ :

$$
\mathrm{E} *{ }_{\lambda}=\int_{0}^{z_{\mathrm{m}}} \mathrm{E}_{\lambda}^{0} \mathrm{~F}_{\lambda \omega} \varepsilon_{\lambda} \mathrm{e}^{\left(-K_{\mathrm{d} \lambda} \mathrm{z}\right)} \mathrm{dz}
$$

Solving this integral yields:

$$
\mathrm{E} *_{\lambda}=-\mathrm{E}_{\lambda}^{0} \mathrm{~F}_{\lambda \omega} \varepsilon_{\lambda}\left(\mathrm{e}^{-K_{\mathrm{d} \lambda} z_{m}}-1\right)\left(1 / K_{\mathrm{d} \lambda}\right)
$$

When the product $K_{\mathrm{d} \lambda} \mathrm{z}_{\mathrm{m}}$ is large, this equation can be approximated by:

$$
\mathrm{E}_{\lambda}^{*}=\mathrm{E}_{\lambda}^{0} \mathrm{~F}_{\lambda \omega} \varepsilon_{\lambda}\left(1 / K_{\mathrm{d} \lambda}\right)
$$

The total biologically effective dose rate for the water column $\left(\mathrm{E}^{*}\right)$ can then be calculated by integration over the entire UV band:

$$
\mathrm{E}^{*}=\int_{290}^{400} \mathrm{E}_{\lambda}^{0} \mathrm{~F}_{\lambda \omega} \varepsilon_{\lambda}\left(1 / K_{\mathrm{d} \lambda}\right) \mathrm{d} \lambda
$$

\section{DEFINITION OF AN UNDERWATER BIOLOGICAL UV EXPOSURE INDEX}

The aim of this study was to develop and apply a simple measure of biological UV exposure that would allow us to compare the effects of changes in water transparency (quantified by the optical depth term $1 / K_{\mathrm{d}}$ ) and ozone depletion in the Arctic Ocean. To achieve this, we modified the $T^{*}$ approach of Vincent et al. (1998) and Pienitz and Vincent (2000), in which the terms $\mathrm{E}_{\lambda}^{0}$ and $\varepsilon_{\lambda}$ in Equation 6 are expressed on relative scales (indicated by the subscript $r$ ):

$$
\mathrm{T}_{\lambda}^{*}=\mathrm{E}_{\lambda \mathrm{r}}^{0} \mathrm{~F}_{\lambda \omega} \varepsilon_{\lambda \mathrm{r}}\left(1 / K_{\mathrm{d} \lambda}\right)
$$

$\mathrm{T}$ refers to the transparency of the water column for UV radiation (a function of $1 / \mathrm{K}_{\mathrm{d}}$, with units in $\mathrm{m}$ ), and the * superscript (T-star) indicates that the index is biologically weighted. For $\mathrm{E}_{\lambda r}^{0}$ we used a data set for incident radiation that is relevant to studies in northern polar regions, specifically a surface incident UV spectrum from the NSF monitoring station at Barrow, Alaska $\left(71.322^{\circ} \mathrm{N}, 156.60^{\circ} \mathrm{W}\right)$ 
(a)

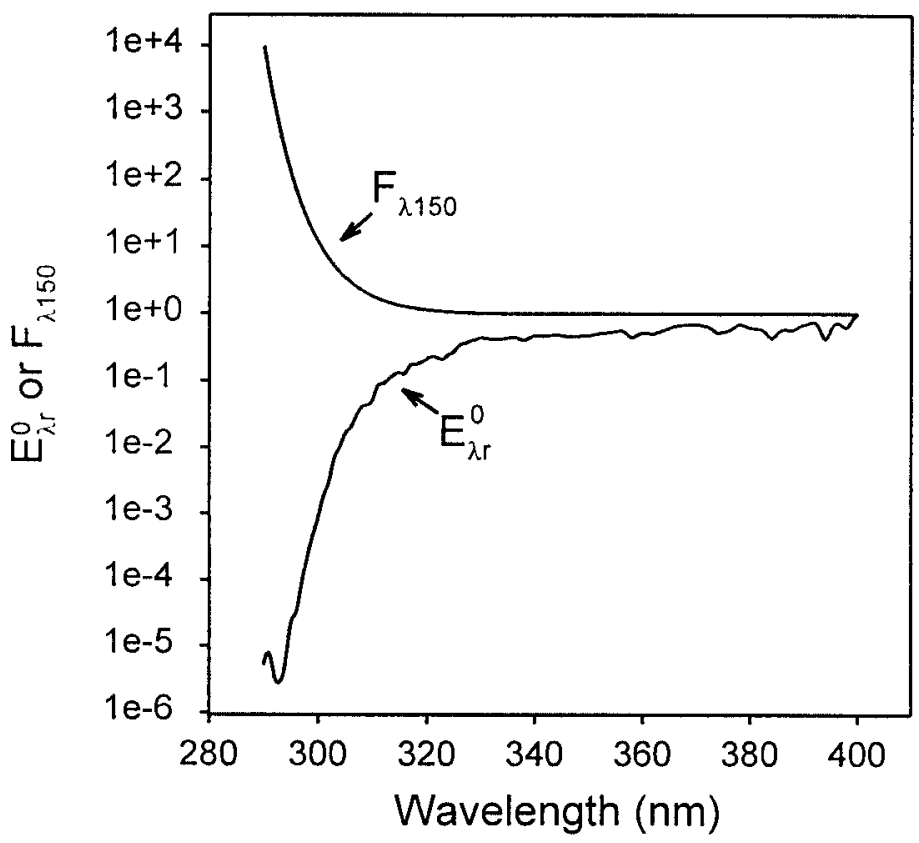

(b)

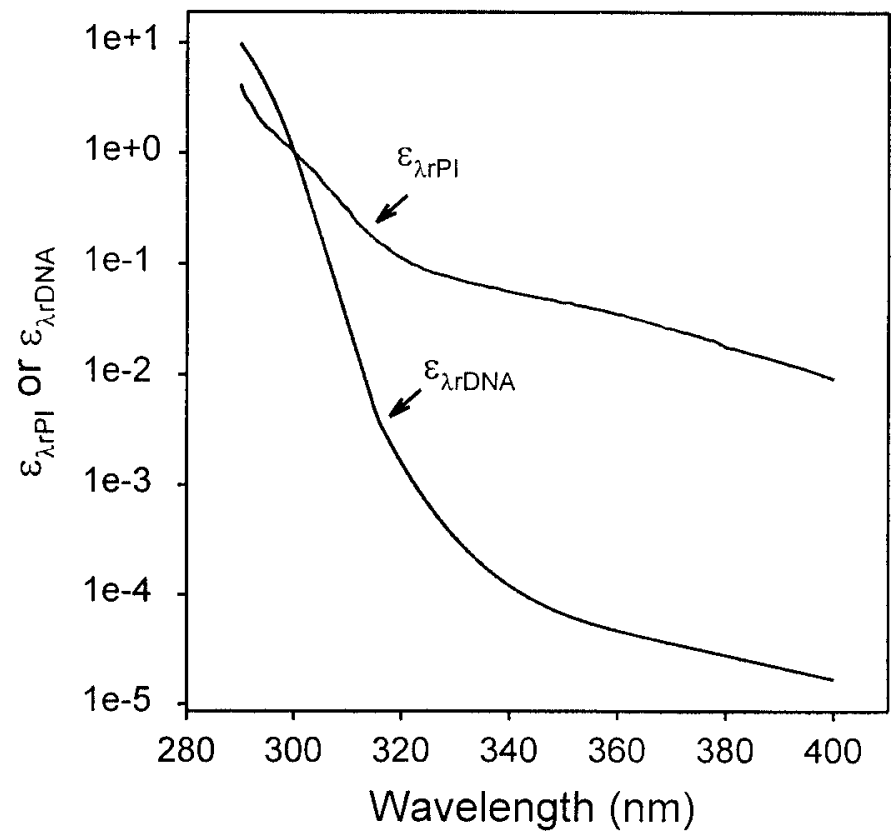

FIG. 2. Plots of (a) normalised surface irradiance and F (for ozone $=150$ DU), and (b) biological weighting factors used in this study.

under clear-sky conditions at the lowest zenith angle $\left(48.02^{\circ}\right)$ on 20 June 1995 at $0.5 \mathrm{~nm}$ resolution (World Ozone and Ultraviolet Radiation Data Center Database, World Meteorological Organization, Toronto). As this data set was for wavelengths shorter than $325 \mathrm{~nm}$, it was extended out to the full UV spectrum using reference data from a lower-latitude site (Lake Lacawac, Pennsylvania: Kirk et al., 1994). The data were then converted to a scale of relative energy flux by normalization to 1.0 at $400 \mathrm{~nm}$ (Fig. 2a). The biological weighting factors (BWFs) were similarly normalized by dividing each value by $\varepsilon_{300}$. BWFs that estimated the wavelength-dependent UV damage for two different biological components were used in this study (Fig. 2b). $T^{*}{ }_{\lambda \mathrm{PI}}$ values were calculated using weighting factors derived for UV-photoinhibition of photosynthesis of a marine diatom $\left(\varepsilon_{\lambda_{\mathrm{rP}}} ;\right.$ Cullen et al., 1992). These BWFs also gave appropriate weightings for the UV-inhibition of growth by high latitude cyanobacteria (Quesada and Vincent, 1997). A second set of values $\left(\mathrm{T}^{*}{ }_{\lambda \mathrm{DNA}}\right)$ were calculated using the BWF for photochemical damage of DNA $\left(\varepsilon_{\lambda_{\mathrm{rDNA}}}\right)$. This curve, which was derived from that of Setlow (1974), may be more appropriate for modelling the effect of UV radiation on certain microbial components of the Arctic Ocean food web such as heterotrophic bacteria (Jeffrey et al., 1996). The wavelength range of this BWF was extended from the original $365 \mathrm{~nm}$ to $400 \mathrm{~nm}$ by loglinear extrapolation using the equation:

$$
\varepsilon_{\lambda \mathrm{rDNA}}=10^{0.975 \log \left(\varepsilon_{(\lambda-1) \mathrm{rDNA}}\right)}
$$

$\mathrm{T}^{*} \lambda$ was integrated over the wavelength range for UV radiation to give the underwater biological UV exposure index, $\mathrm{T}^{*}$ (units: $\mathrm{m}$ ):

$$
\mathrm{T}^{*}=\int_{290}^{400} \mathrm{E}_{\lambda \mathrm{r}}^{0} \mathrm{~F}_{\lambda \omega} \varepsilon_{\lambda r}\left(1 / K_{\mathrm{d} \lambda}\right) \mathrm{d} \lambda
$$

$\mathrm{T}^{*}$ (T-star, referred to as "weighted transparency" in Pienitz and Vincent, 2000) is analogous to other oceanographic and limnological indices based on $1 / \mathrm{K}_{\mathrm{d}}$, such as critical depth and average water column irradiance. Larger values of $\mathrm{T}^{*}$ indicate higher biologically effective exposure to UV radiation in the surface mixed layer, and thus higher potential for photobiological damage. It is important to note that each biological weighting function applies to a specific type of biological damage; therefore, it is not possible to compare $\mathrm{T}_{\mathrm{PI}}$ and $\mathrm{T}^{*}{ }_{\mathrm{DNA}}$ values directly. Dividing these values by the depth of the mixed layer $Z_{m}$ provides a relative measure of the average biologically effective UV flux experienced by the plankton. For shallow $\mathrm{Z}_{\mathrm{m}}$ conditions, however, the product $\mathrm{Z}_{\mathrm{m}} \mathrm{K}_{\mathrm{d}}$ may be small for some wavelengths, and the full integral form (equation 5) should be adopted. In the absence of data on mixed-layer depth for the range of Arctic Ocean sites considered here, we restricted our analysis to $T^{*}$ rather than $T^{*} / \mathrm{Z}_{\mathrm{m}}$.

To calculate $\mathrm{T}^{*}, \mathrm{~T}^{*}{ }_{\lambda}$ values were determined at $1 \mathrm{~nm}$ intervals and then summed over the range from 290 to 400 $\mathrm{nm}$. The enhancement factor due to ozone depletion $\left(\mathrm{F}_{\lambda \omega}\right)$ was modelled from the data of Smith et al., 1992. Equations were developed to describe $F_{\lambda \omega}$ at a zenith angle of $45^{\circ}$ and ozone levels of 240 and 150 DU:

$$
\begin{aligned}
& \log \mathrm{F}_{\lambda 240}=10^{-2.474 \times 10^{-4} \lambda^{2}+9.111 \times 10^{2} \lambda-5.335} \\
& \log \mathrm{F}_{\lambda 150}=10^{-2.004 \times 10^{-4} \lambda^{2}+6.142 \times 10^{2} \lambda-0.3561}
\end{aligned}
$$


A plot of $\mathrm{F}_{\lambda 150}$ as a function of wavelength is shown in Fig. 2a. Values at other ozone depletion levels were calculated by interpolation.

Data for $K_{\mathrm{d} \lambda}$ are relatively scarce, as they require the use of expensive optical equipment. No data appeared to be available for the Arctic Ocean at the time of our analysis. A number of approaches are available for the prediction of transparency from other, more easily measured, optical and chemical characteristics of water. In this study, the approach employed made use of the concentrations of CDOM and DOC.

Laurion et al. (1997) reported a set of $K_{\mathrm{d} \lambda}$ and CDOM data for high-latitude lakes and rivers that ultimately discharge into the Arctic Ocean. The concentration of CDOM measured fluorometrically $\left(\mathrm{F}_{\mathrm{CDOM}}\right)$ was related to $K_{\mathrm{d} 380}$ by the equation:

$$
K_{\mathrm{d} 380}=10^{1.153+0.973 \log \mathrm{F}_{\mathrm{CDOM}}}
$$

$K_{\mathrm{d} \lambda}$ at other wavelengths can then be calculated by combining this equation with another determined by Laurion et al. (1997), which related $K_{\mathrm{d} \lambda}$ to $K_{\mathrm{d} 380}$ :

$$
\mathrm{K}_{\mathrm{d} \lambda}=10^{1.153+0.973 \log \mathrm{F}_{\mathrm{CDOM}}} \mathrm{e}^{-\mathrm{S}(\lambda-380)}
$$

The parameter $\mathrm{S}$ is the slope of the log-linear plot of absorbance with wavelength, and has been found to be relatively constant (circa 0.015) for many marine and freshwaters (Bricaud et al., 1981; but see Markager and Vincent [2000] for evidence of variation). Similarly, $\mathrm{F}_{\mathrm{CDOM}}$ has been found to be independent of salinity (Determann et al., 1994; J. Gibson, unpubl. data), indicating that the fluorophores in CDOM may behave similarly in marine and fresh waters and that measurements of $\mathrm{F}_{\mathrm{CDOM}}$ in marine and freshwaters may be comparable. These observations indicate that Equation 13 should hold for a wide range of marine and freshwater aquatic systems irrespective of salinity.

$\mathrm{T}^{*}{ }_{\lambda}$ can therefore be calculated as a function of CDOM fluorescence. A problem with this approach, however, is that there is little uniformity between studies in the measurement of CDOM fluorescence; the equations given here apply only to data obtained using the instrument settings (excitation $348 \mathrm{~nm}$, slit width $5 \mathrm{~nm}$ ) used by Laurion et al. (1997), with CDOM concentration (units: $\mathrm{nm}^{-1}$ ) calculated by dividing the emission peak height at $450 \mathrm{~nm}$ by the area of the Raman water peak. Use of other excitation and emission wavelengths or standardization procedures will result in different relationships. However, other procedures should yield results that are directly proportional to $\mathrm{F}_{\mathrm{CDOM}}$ measured as described above.

A second approach to estimating $K_{\mathrm{d} \lambda}$ values is to use the relationship between $K_{\mathrm{d} \lambda}$ and DOC determined by Vincent et al. (1998) for high latitude freshwaters:

$$
\begin{aligned}
& K_{\mathrm{d} 305}=10^{-0.12+1.68 \log [\mathrm{DOC}]} \\
& K_{\mathrm{d} 320}=10^{-0.42+1.98 \log [\mathrm{DOC}]}
\end{aligned}
$$

$$
\begin{aligned}
& K_{\mathrm{d} 340}=10^{-0.58+2.04 \log [\mathrm{DOC}]} \\
& K_{\mathrm{d} 380}=10^{-0.75+1.91 \log [\mathrm{DOC}]}
\end{aligned}
$$

The square brackets indicate concentration $\left(\mathrm{g} \mathrm{C} \mathrm{m}^{-3}\right)$. Values of $K_{\mathrm{d} \lambda}$ at other wavelengths can be determined by log-linear interpolation. This approach assumes that all DOC in aquatic ecosystems has similar optical properties. This will not always be the case. $K_{\mathrm{d} \lambda}$ for water in which the majority of the DOC is produced by phytoplankton, seaice algae or benthic phototrophs (periphyton and macrophytes) will be underestimated by these equations because this autochthonous DOC is not strongly coloured. This underestimation in turn will lead to underestimation of biological UV exposure by T*. For the Arctic Ocean, it is likely that water in which the DOC stems largely from riverine input will conform more closely to Equations $14 a-d$ than will water distant from the inputs, for which local production of non-coloured DOC by phytoplankton and sea-ice algae will be more important.

\section{MODEL APPLICATION}

The biological exposure index $\mathrm{T}^{*}$ was calculated for both the phytoplankton inhibition and DNA damage BWFs, for stratospheric ozone levels from 150 to $330 \mathrm{DU}$, for CDOM concentrations from 0.025 to $0.5 \mathrm{~nm}^{-1}$ (using equations 12 and 13 to estimate $\mathrm{K}_{\mathrm{d} \lambda}$ ), and for DOC concentrations from 0.5 to $7 \mathrm{~g} \mathrm{C} \mathrm{m}^{-3}$ (using equations $14 \mathrm{a}-\mathrm{d}$ to estimate $\left.\mathrm{K}_{\mathrm{d} \lambda}\right)$. Figure 3 gives isopleth diagrams comparing the effects of ozone level with those of $\operatorname{DOC}(3 a, b)$ and CDOM (3c, d). Underwater biological UV exposure for both biological weighting functions is strongly influenced by CDOM and DOC, with a sharp rise in $\mathrm{T}^{*}$ values at CDOM concentrations below $0.05 \mathrm{~nm}^{-1}$ and DOC concentrations below $2 \mathrm{mg} \mathrm{L}^{-1}$ (Fig. 3). This sharp rise is a result of the high transparencies at these concentrations, and implies that dissolved organic matter provides a highly effective UV-screening of the water column. $T^{*}$ is also influenced by stratospheric ozone, but to an extent that differs considerably between the two biological effects. The $\mathrm{T}_{\mathrm{PI}}$ isopleths were almost vertical, indicating the small effect of ozone relative to that of dissolved organic matter. This response implied that UV-A, which is relatively unaffected by ozone but strongly influenced by dissolved organic matter, plays a dominant role in controlling total $\mathrm{T}_{\mathrm{PI}}^{*}$. This supposition was confirmed by calculation of the percentage contributions of UV-B to $\mathrm{T}^{*}{ }_{\mathrm{PI}}$ (Fig. 4). These ranged from less than $10 \%$, at low DOC and high $\mathrm{O}_{3}$, to $25 \%$ at high DOC and low $\mathrm{O}_{3}$. In contrast, the $\mathrm{T}^{*}{ }_{\mathrm{DNA}}$ isopleths exhibit greater nonlinearity, reflecting the strong UV-B influence associated with ozone depletion. UV-B accounted for $75 \%$ of total $\mathrm{T}^{*}{ }_{\mathrm{DNA}}$ at low DOC concentrations and high $\mathrm{O}_{3}$ concentrations, rising to more than $99 \%$ at an $\mathrm{O}_{3}$ level of $150 \mathrm{DU}$ and DOC of $7 \mathrm{~g} \mathrm{C} \mathrm{m}^{-3}$ 
(a)

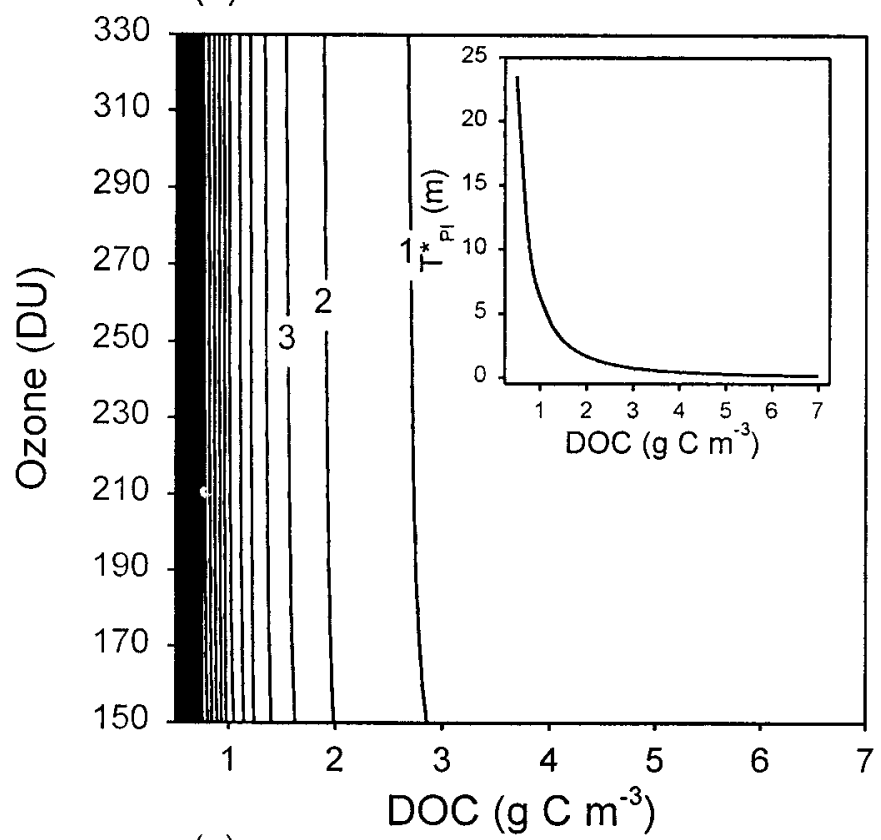

(c)

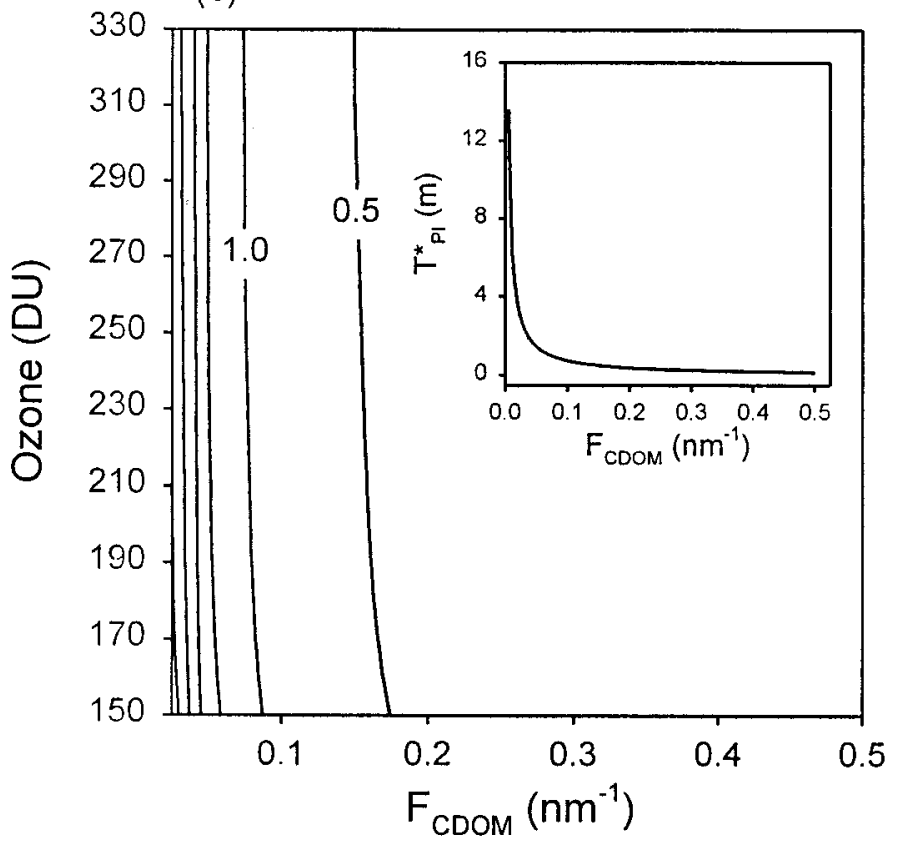

(b)

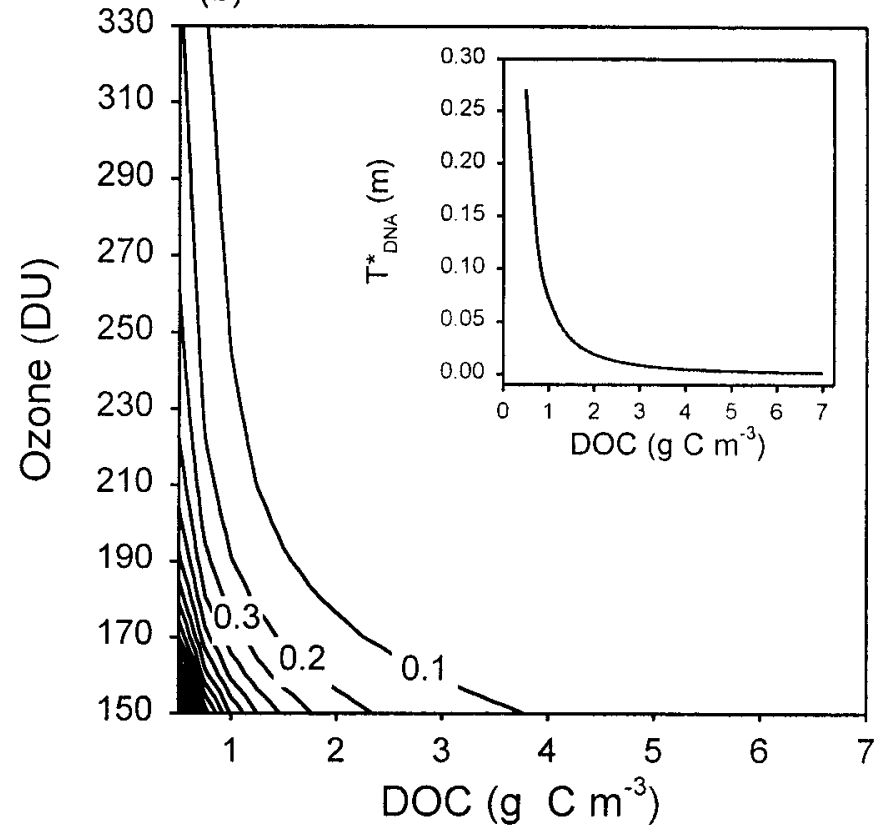

(d)

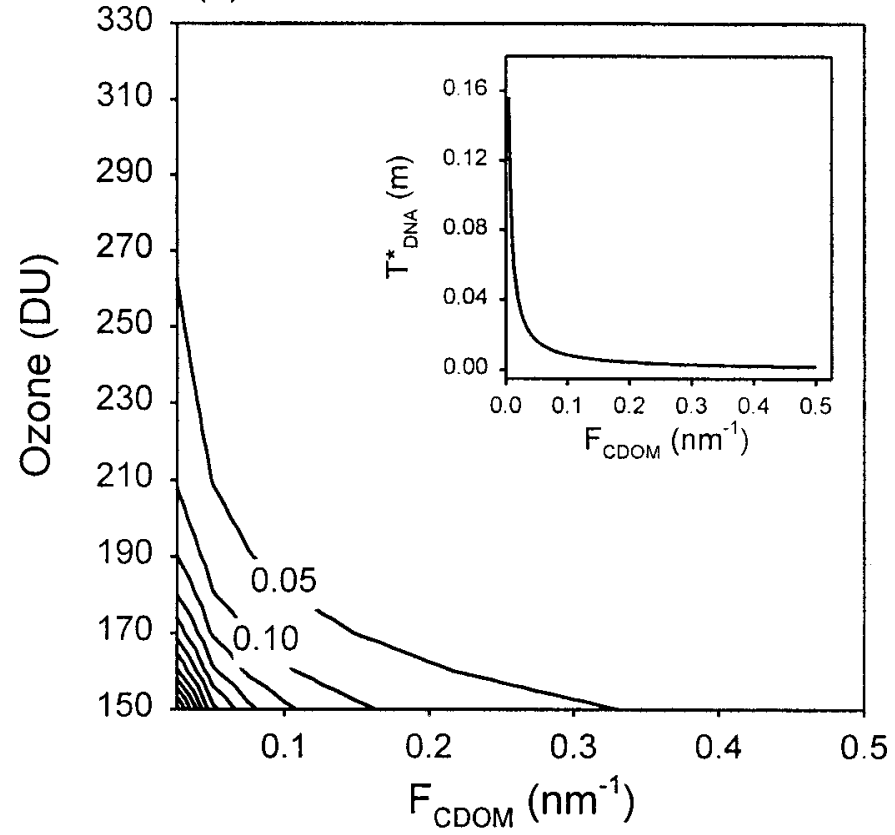

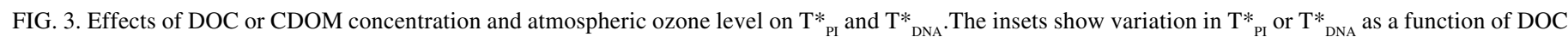
or CDOM at an ozone level of 330 DU.

(Fig. 4). These differences in behaviour reflect the characteristics of the BWFs for the two effects; $\varepsilon_{\mathrm{rDNA}}$ rises more rapidly than $\varepsilon_{\mathrm{rPI}}$ at shorter wavelengths, and $\varepsilon_{\mathrm{rDNA}}$, unlike $\varepsilon_{\mathrm{rPI}}$, is negligible in the UV-A waveband. As it is shortwavelength UV-B that will show the largest increase in radiation flux on reduction of the stratospheric ozone (Fig. 2a), the effect of the depletion is greater for $\mathrm{T}^{*}{ }_{\text {DNA. }}$.

Although the value of $S$ in Equation 13 is often near $0.015 \mathrm{~nm}^{-1}$, it can vary significantly (Markager and Vincent, 2000) as a result of differences in the characteristics of the CDOM source, or because of photobleaching and other degradation processes (but not because of dilution with lower CDOM water). The sensitivity of $\mathrm{T}^{*}{ }_{\mathrm{PI}}$ to $\mathrm{S}$ was determined over a range of CDOM concentrations. $\mathrm{T}^{*}{ }_{\mathrm{PI}}$ increased slightly with decreasing $S$, though the effect was not particularly strong (Fig. 5a), and T* ${ }_{\text {DNA }}$ similarly showed little response to moderate changes in $\mathrm{S}$.

Calculations that use the concentration of DOC as a proxy for $\mathrm{K}_{\mathrm{d}}$ assume that the optical characteristics of the DOC are the same as those for DOC in the high-latitude lakes and rivers for which the relationships were obtained. As riverine inputs are diluted in the marine environment, the percentage of the total DOC that has originated from terrestrial ecosystems will decrease. The effect of this 
(a)

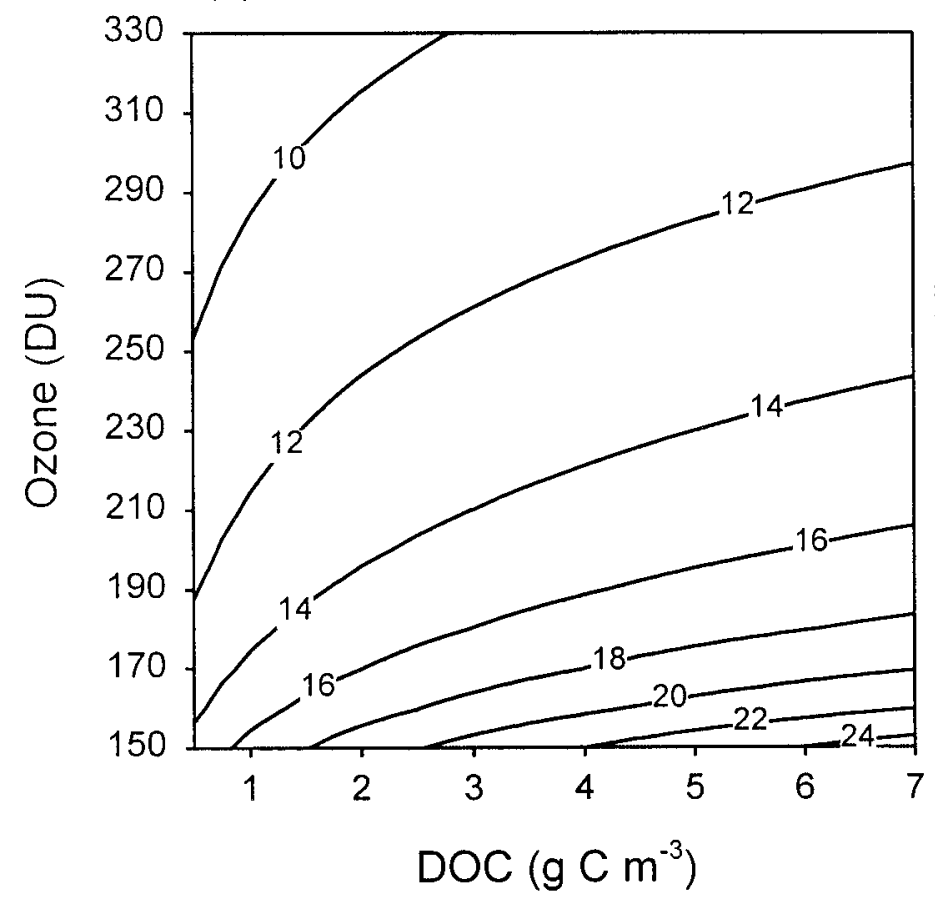

(b)

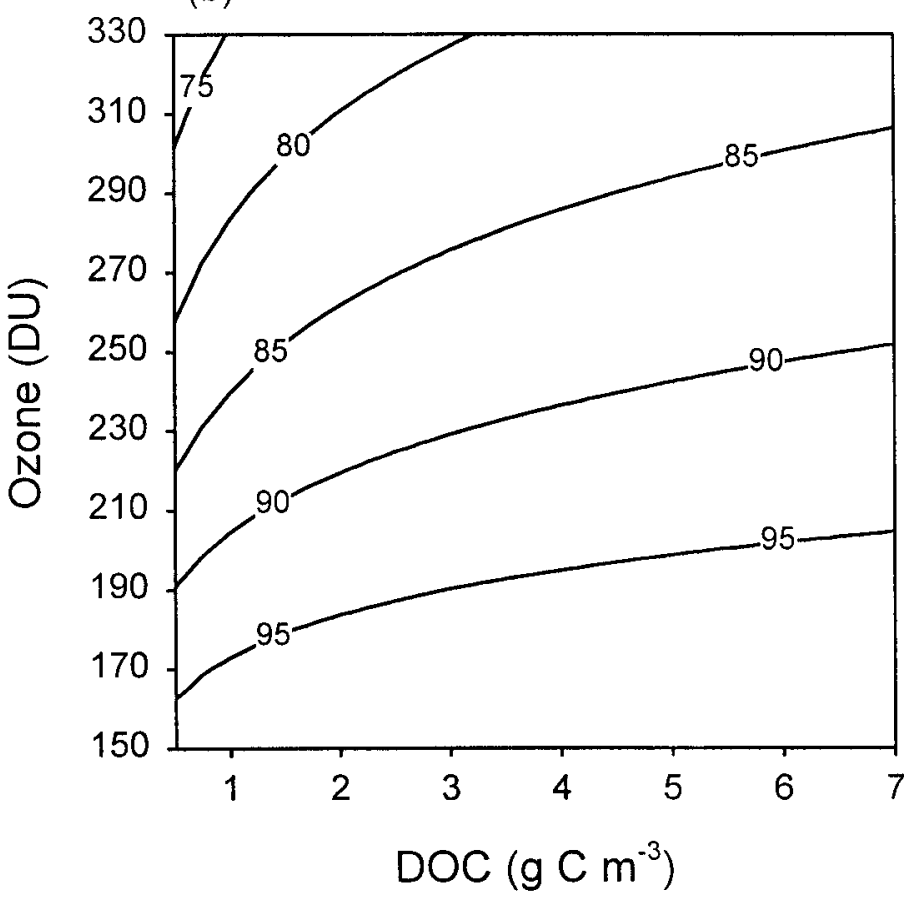

FIG. 4. Percentage contribution of UV-B $(290-320 \mathrm{~nm})$ as a function of DOC and atmospheric ozone concentrations to total (a) $\mathrm{T}^{*}{ }_{\mathrm{PI}}$ and (b) $\mathrm{T}^{*}{ }_{\mathrm{DNA}}{ }^{*}$

dilution is shown in Fig. 5b. As the percentage of terrestrial DOC decreases, $\mathrm{T}^{*}{ }_{\mathrm{PI}}$ increases. This effect is particularly marked at low DOC concentrations, where $\mathrm{T}_{\mathrm{PI}}$ is a highly sensitive function of DOC. Similar results were obtained for $\mathrm{T}^{*}{ }_{\mathrm{DNA}}$.

In the absence of CDOM measurements, we used total DOC concentrations in applying the model to the Arctic Ocean region. These DOC values will probably include a percentage of noncoloured, marine-derived material, which will, as discussed above, result in an underestimate of the true $\mathrm{T}^{*}$. This effect will be most pronounced in offshore areas with little influence from the major river inputs. $\mathrm{T}^{*}$ values were computed for DOC concentrations that have been reported for the Arctic Ocean (Fig. 6), and the effects of ozone or CDOM depletion were then evaluated. Both analyses show a huge level of regional variation in the Arctic Ocean in biological UV exposure associated with the discharge of the large northern rivers. For the DNA damage index, values varied (maximum-minimum as \% of minimum) by $606 \%$ inshore, $746 \%$ offshore, and $17836 \%$ overall. For the Cullen et al. (1992) photoinhibition index, the values varied by $756 \%$ inshore, $910 \%$ offshore and $28611 \%$ overall. The underestimation of $\mathrm{T}^{*}$ resulting from the presence of noncoloured, autochthonous organic carbon in the offshore region will result in underestimation of the variability within the Arctic Ocean. Assuming that Wheeler et al. (1997) estimated correctly that only a quarter of the DOC in the Nansen Basin in the central Arctic Ocean is from riverine sources, $\mathrm{T}_{\mathrm{PI}}$ and $\mathrm{T}^{*}{ }_{\mathrm{DNA}}$ could be as high as $160.5 \mathrm{~m}$ and $1.15 \mathrm{~m}$, respectively.

These analyses show that the effects of moderate depletion of ozone are likely to be minor compared to those induced by changes in the concentration of terrestrially derived dissolved organic matter (Table 1). A $20 \%$ decrease in ozone resulted in a mean increase of $\mathrm{T}_{\mathrm{PI}}$ of $2 \%$, whereas a $20 \%$ decrease in DOC caused more than an order of magnitude greater effect. The same analysis for $\mathrm{T}^{*}{ }_{\mathrm{DNA}}$ again showed a strong effect caused by changing DOC, but, unlike the phytoplankton response, ozone depletion caused a change of similar magnitude to the CDOM effect (mean of $44 \%$ increase in $\mathrm{T}^{*}$ ). These differences in response are consistent with the importance of UV-A in UV photoinhibition but not in DNA damage.

\section{DISCUSSION}

Several studies have drawn attention to the role of CDOM in controlling underwater spectral irradiance (Scully and Lean, 1994; Morris et al., 1995; Arrigo and Brown, 1996; Laurion et al., 1997) and to the potential effect of climate change on catchment hydrology and vegetation processes that will in turn affect CDOM export and the biological exposure to UV in downstream receiving waters (Schindler et al., 1996; Williamson et al., 1996; Schindler, 1998). These previous studies, however, lacked a way of evaluating the effects of changing CDOM on a quantitative and biologically relevant scale. The $T^{*}$ parameter defined here provides an appropriate scale that can be tailored to individual biological processes and allows direct comparison with the effects of ozone depletion. In another application of T*, Pienitz and Vincent (2000) have shown that northern lakes experienced major variations in underwater UV exposure throughout the Holocene caused 
(a)

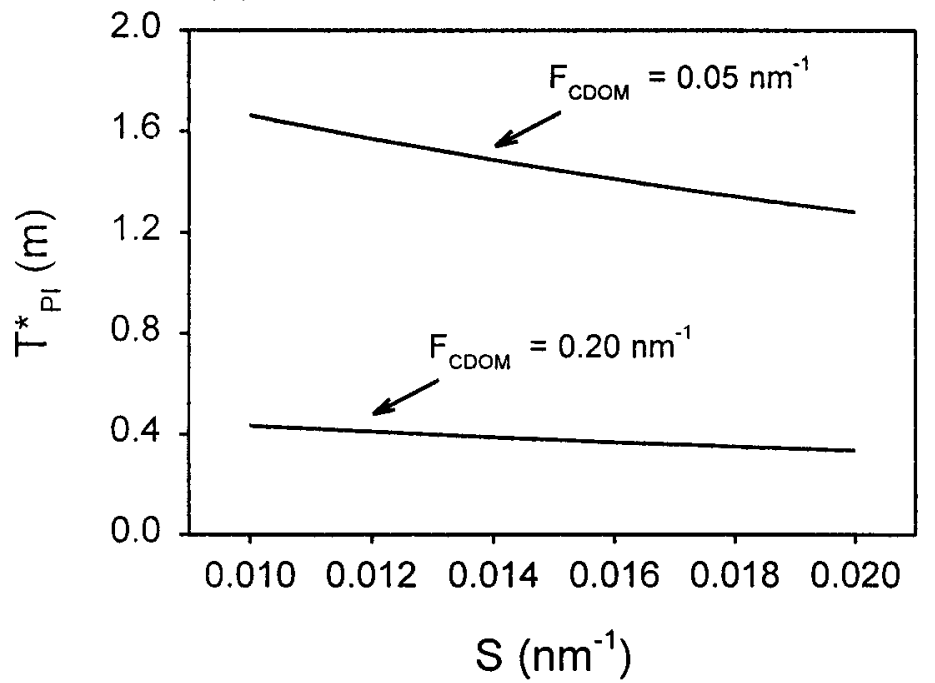

(b)

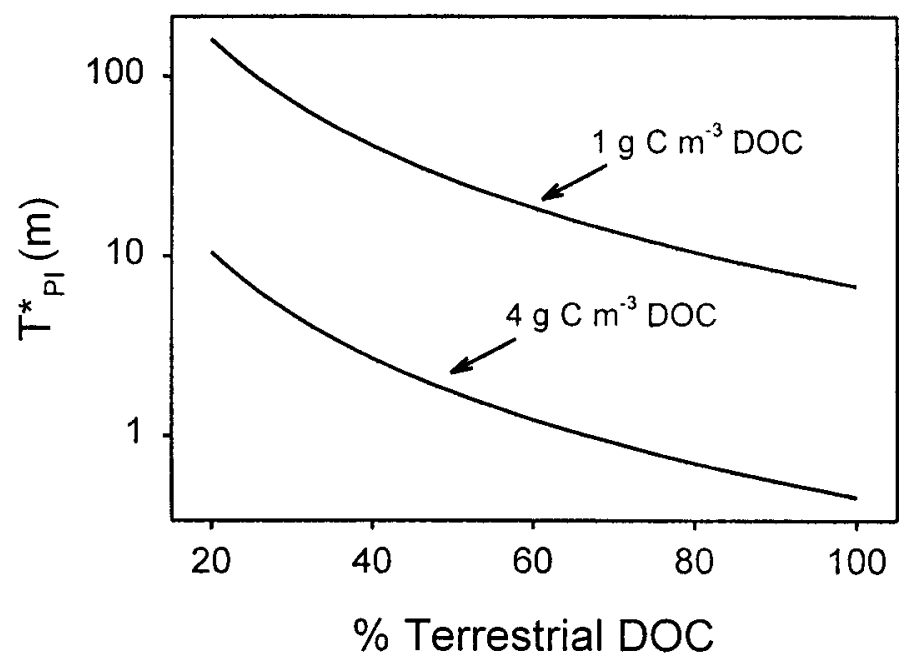

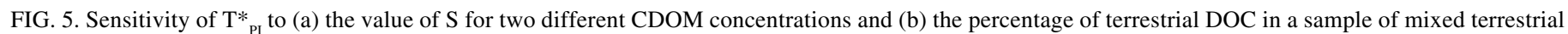
and autochthonous marine origin.

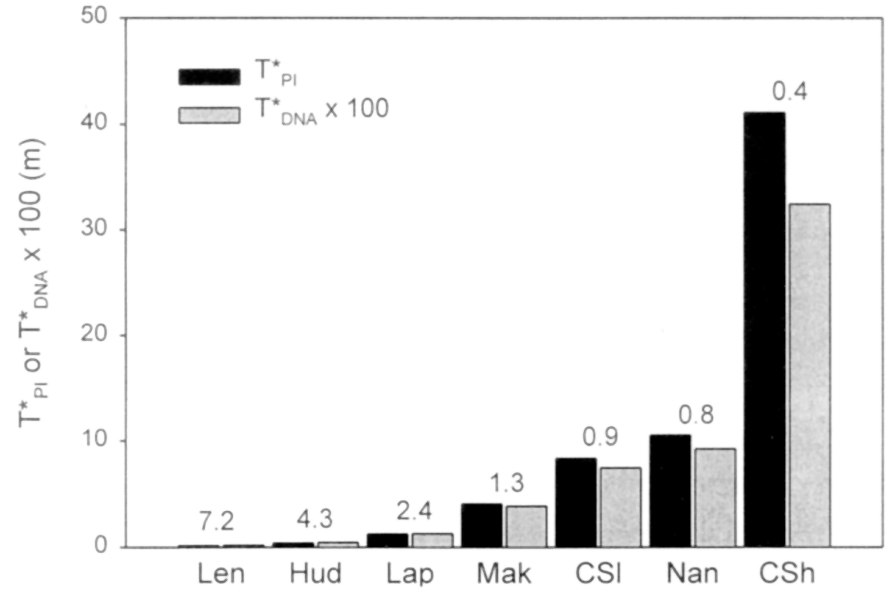

FIG. 6. Calculated $\mathrm{T}_{\mathrm{PI}}^{*}$ and $\mathrm{T}^{*}{ }_{\mathrm{DNA}}$ values for DOC concentrations reported from the Arctic Ocean. The DOC concentrations $\left(\mathrm{g} \mathrm{C} \mathrm{m}^{-3}\right)$ for each site are given above the columns. The data sources are given in Table 1. Abbreviations: Len = Lena River Delta; Hud = Hudson Bay; Lap = Laptev Sea; Mak = Makarov Basin $; \mathrm{CSl}=$ Chukchi Sea Slope $;$ Nan = Nansen Basin $;$ and CSh $=$ Chukchi Sea Shelf. $\mathrm{T}^{*}$ PI and $\mathrm{T}^{*}{ }_{\mathrm{DNA}}$ for the Lena River Delta were $0.14 \mathrm{~m}$ and $0.0018 \mathrm{~m}$, respectively.

by climate-related changes in vegetation and CDOM export. These variations far exceeded the effects of moderate ozone depletion.

The absolute values of $\mathrm{T}^{*}$ are highly dependent on the choice of BWF (cf. Neale et al., 1998). Irrespective of this choice, all the calculations made here draw attention to the importance of CDOM in controlling biological exposure, and to the large spatial variability in underwater UV across the Arctic Ocean. For each of the biological weighting functions used here, the $\mathrm{T}^{*}$ values for this region vary by more than $500 \%$. This degree greatly exceeds the $2-55 \%$ change associated with moderate ozone depletion. These estimates of variability are likely to be conservative, as additional factors will contribute to the overall variation in underwater UV exposure. These factors include the effects
TABLE 1.Calculated percentage changes in $\mathrm{T}^{*}$ and $\mathrm{T}^{*}{ }_{\mathrm{DNA}}$ resulting from a $20 \%$ decrease in DOC (from reported concentrations) or ozone concentration (from 330 DU to 264 DU).

\begin{tabular}{|c|c|c|c|c|c|}
\hline \multirow[t]{2}{*}{ Location } & \multirow[t]{2}{*}{$\begin{array}{l}\text { DOC Conc. } \\
\qquad \mathrm{g} \mathrm{C} \mathrm{m}^{-3}\end{array}$} & \multicolumn{2}{|c|}{$\begin{array}{c}20 \% \text { Decrease } \\
\text { in DOC }\end{array}$} & \multicolumn{2}{|c|}{$\begin{array}{l}20 \% \text { Decrease } \\
\text { in Ozone }\end{array}$} \\
\hline & & $\mathrm{T}_{\text {PI }}^{*}$ & $\mathrm{~T}^{*}{ }_{\text {DNA }}$ & $\mathrm{T}^{*}{ }_{\mathrm{PI}}$ & $\mathrm{T}_{\text {DNA }}^{*}$ \\
\hline \multicolumn{6}{|l|}{ Inshore: } \\
\hline Lena R. Delta & $7.2^{1}$ & 54.6 & 48.4 & 2.8 & 54.9 \\
\hline Laptev Sea & $2.4^{1}$ & 54.8 & 49.1 & 2.3 & 46.6 \\
\hline Hudson Bay & $4.3^{2}$ & 54.7 & 48.8 & 2.6 & 50.9 \\
\hline \multicolumn{6}{|l|}{ Offshore: } \\
\hline Makarov Basin & $1.3^{3}$ & 54.9 & 49.5 & 2.1 & 42.4 \\
\hline Nansen Basin & $0.8^{3}$ & 54.9 & 49.8 & 2.0 & 39.2 \\
\hline Chukchi Sea Shelf & $0.4^{3}$ & 55.0 & 50.3 & 1.8 & 35.1 \\
\hline Chukchi Sea Slope & $0.9^{3}$ & 54.9 & 49.8 & 2.0 & 40.0 \\
\hline
\end{tabular}

Data sources:

${ }^{1}$ Cauwet and Sidorov, 1996.

${ }^{2}$ Laurion et al., 1997.

${ }^{3}$ Wheeler et al., 1997.

of cloud, snow and ice cover, changes in the spectroscopic properties of the CDOM, and variations in mixed layer depth, $\mathrm{Z}_{\mathrm{m}}$.

Ice and snow cover play an important role in the mitigation of UV-induced damage in polar marine ecosystems (Perovich et al., 1998). The period of ice cover in the Arctic is shortest in the south over the continental shelves, and thus the productive waters in this region will be most exposed to incident UV radiation. Fortuitously, large parts of this region (e.g., the Siberian Shelf) are also characterized by the highest terrestrial DOC concentrations, and thus by natural UV-screening. The water column in the permanently ice-covered central Arctic will experience a far lower $T^{*}$ than calculated here because the snow and ice layer attenuates and may completely absorb and reflect 
incident UV. The contraction and eventual loss of the Arctic ice cap associated with global warming would greatly increase the exposure of marine organisms to UV radiation in the north polar region, particular in the offshore waters that are relatively unprotected by CDOM.

Some of the Arctic river inflows are also rich in particulate material (Burenkov et al., 1997), which may increase scattering and attenuation of UV in the nearshore waters, before this material is sedimented or diluted out. As the Arctic river plumes extend out into and mix with the surrounding seawater, some changes are also likely to occur in the spectroscopic characteristics of the CDOM, for example, in the value of S in Equation 13 (de Souza Sierra et al., 1991; Ferrari and Dowell, 1998). A study on the Lena River showed a negative linear relationship between DOC and salinity, implying that DOC traced the freshwater dilution curve (Cauwet and Sidorov, 1996). However, there was also evidence of change in the molecular weight distribution of DOC, which could potentially affect UV absorption and scattering. Flocculation and loss of DOC occur across the freshwater-saltwater front of estuaries (e.g., Mantoura, 1987) and could be accompanied by spectroscopic shifts. The gradual aging of CDOM once it enters the Arctic Basin, for example, through photobleaching processes (Kieber et al., 1990), may also influence the chromophoric characteristics of these materials. These biogeochemical and photochemical effects are likely to act as additional controls on the way in which CDOM affects the site-to-site variation in UV exposure.

Dissipation and dilution of the DOC-rich plumes as they reach further into the ocean will result in an increase in $\mathrm{T}^{*}$. This effect will be particularly important in the zones where the concentration of DOC is less than $2 \mathrm{~g} \mathrm{C} \mathrm{m}^{-3}$, as small variations in DOC below this threshold result in large changes in exposure. This effect may be offset, however, by the reduced freshwater stabilization of the water column offshore, deeper mixing of the plankton, and less frequent exposure to near-surface UV radiation.

Major changes in the surface circulation in the Arctic Ocean in recent years (Dickson, 1999) are likely to have caused large regional variations in CDOM and underwater UV exposure. For example, in the early 1990s there was an eastward redistribution of the surface freshwater layer from the Eurasian Basin and a greater freshwater (thus CDOM) influence on the Beaufort Sea. These spatial and temporal shifts may also have an opposing effect on primary production: the shading caused by CDOM reduces the availability of photosynthetically active radiation (Arrigo and Brown, 1996; Vincent et al., 1998). This latter effect, however, may be less important for Arctic Ocean phytoplankton than for more deeply mixed, lightlimited communities in the Southern Ocean.

The catchments that drain into the Arctic Ocean are potentially subject to a number of climate and land-use changes that could cause significant variation in CDOM export to the ocean. In regions of the Arctic Ocean that are strongly influenced by riverine input, these changes are probably more important than ozone depletion to the penetration of UV into the water. Processes that decrease the flux of CDOM to the ocean (e.g., catchment acidification, water diversion) will have a negative impact on marine communities in terms of photobiological cell damage, as the average biologically effective dose rate will increase. Conversely, any increase in oceanic CDOM resulting from processes that increase organic carbon export (e.g., forest clearance, precipitation increase, melting of the permafrost) will tend to counteract the increase in UV radiation at the Earth's surface resulting from declining atmospheric ozone.

In summary, the index $\mathrm{T}^{*}$ ( $\mathrm{T}$-star, weighted transparency) provides a useful and relatively simple approach to comparing the effects of changing spectral attenuation in the atmosphere (ozone depletion) and in the water column (CDOM) on biologically effective exposure to UV radiation in underwater environments. The calculations for the Arctic Basin illustrate an application of this approach, and emphasize the importance of CDOM in controlling the large-scale spatial and temporal variability in the spectral irradiance regime for aquatic biota, particularly in the shelf environment. The results show that for the Arctic Ocean, underwater UV exposure is highly dependent not only on stratospheric ozone levels, but also on climate and landuse changes in the catchments of the large inflowing rivers.

\section{ACKNOWLEDGEMENTS}

Our research on the bio-optics of high-latitude waters is supported by the Fonds pour la Formation de Chercheurs et l'Aide à la Recherche (Québec) and the Natural Sciences and Engineering Research Council of Canada, with logistical support from Centre d'Études Nordiques and the Polar Continental Shelf Project (this is PCSP publication no. 01899). We thank three referees for their insightful review comments and suggestions.

\section{REFERENCES}

AAGAARD, K., and CARMACK, E.C. 1989. The role of sea ice and other freshwater in the Arctic circulation. Journal of Geophysical Research 94:14,485-14,498.

ARRIGO, K.R., and BROWN, C.W. 1996. Impact of chromophoric dissolved organic matter on UV inhibition of primary productivity in the sea. Marine Ecology Progress Series 140:207-216.

BAUCH, D., SCHLOSSER, P., and FAIRBANKS, R.G. 1995. The distribution of $\mathrm{H}_{2}{ }^{18} \mathrm{O}$ in the Arctic Ocean: Implication for freshwater balance and the sources of deep and bottom waters. Progress in Oceanography 35:53-80.

BLOUGH, N.V.,ZAFIROU, O.C., and BONILLA, J. 1993. Optical absorption spectra of waters from the Orinoco River outflow: Terrestrial input of colored organic matter to the Caribbean. Journal of Geophysical Research 98:2271-2278. 
BRICAUD, A., MOREL, A., and PRIEUR, L. 1981. Absorption by dissolved organic matter of the sea (yellow substance) in the UV and visible domains. Limnology and Oceanography 26:43-53.

BURENKOV, V.I., KUPTZOV, V.M., SIVKOV, V.V., and SHEVCHENKO, V.P. 1997. Spatial distribution and size composition of suspended matter in the Laptev Sea in AugustSeptember 1991. Oceanology 37:920-927.

CATTLE, H. 1985. Diverting Soviet rivers: Some possible repercussions for the Arctic Ocean. Polar Record 22:485-498.

CAUWET, G., and SIDOROV, I. 1996. The biogeochemistry of Lena River: Organic carbon and nutrients distribution. Marine Chemistry 53:211-227.

CULLEN, J.J., NEALE, P.J., and LESSER, M.P. 1992. Biological weighting function for the inhibition of phytoplankton photosynthesis by ultraviolet radiation. Science 258:646-650.

DE SOUZA SIERRA, M.M., DONARD, O.F.X., and LAMOTTE, M. 1991. Spectral identification and behaviour of dissolved organic fluorescent material during estuarine mixing processes. Marine Chemistry 58:51-58.

DETERMANN, S., REUTER, R., WAGNER, P., and WILLKOMM, R. 1994. Fluorescent matter in the eastern Atlantic Ocean. Part 1. Method of measurement and near-surface distribution. DeepSea Research I, 41:659-675.

DICKSON, R.R. 1999. All change in the Arctic. Nature 397: 389-391.

FERRARI, G.M., and DOWELL, M.D. 1998. CDOM absorption characteristics with relation to fluorescence and salinity in coastal areas of the southern Baltic Sea. Estuarine, Coastal and Shelf Science 47:91-105.

FIOLETOV, V.E., KERR, J.B., WARDLE, D.I., DAVIES, J., HARE, E.W., McELROY, C.T., and TARASICK, D.W. 1997. Long-term ozone decline over the Canadian Arctic to early 1997 from ground-based and balloon observations. Geophysical Research Letters 24:2705-2708.

GORDEEV, V.V, MARTIN, J.M., SIDOROV, I.S., and SIDHOROVA, M.V. 1996. A reassessment of the Eurasian river input of water, sediments, major elements and nutrients to the Arctic Ocean. American Journal of Science 296:664-691.

GREEN, A.E.S., SAWADA, T., and SHETTLE, E.P. 1974. The middle ultraviolet reaching the ground. Photochemistry and Photobiology 19:251-259.

GUAY, C.K., KLINKHAMMER, G.P., FALKNER, K.K., BENNER, R., COBLE, P.G., WHITLEDGE, T.E., BLACK, B., BUSSELL, F.J., and WAGNER, T.A. 1999. High-resolution measurements of dissolved organic carbon in the Arctic Ocean by in situ fiber-optic spectrometry. Geophysical Research Letters 26:1007-1010.

HESSEN, D.O., DE LANGE, H.J., and VAN DONK, E. 1997. UVinduced changes in phytoplankton cells and its effect on grazers. Freshwater Biology 38:513-524.

INTERNATIONAL ARCTIC SCIENCE COMMITTEE. 1995. Effects of increased ultraviolet radiation in the Arctic. IASC Report No. 2. Oslo: IASC. 56 p.

JEFFREY, W.H., AAS, P., LYONS, M.M., COFFIN, R.B., PLEDGER, R.J., and MITCHELL, D.L. 1996. Ambient solar radiation-induced photodamage in marine bacterioplankton. Photochemistry and Photobiology 64:419-427.
KARENTZ, D., BOTHWELL, M.L., COFFIN, R.B., HANSON, A., HERNDL, G.J., KILHAM, S.S., LESSER, M.P., LINDELL, M., MOELLER, R., MORRIS, D.P., NEALE, P.J., SANDERS, R.W., WEILER, C.S., and WETZEL, R.C. 1994. Impact of UV$B$ radiation on pelagic freshwater ecosystems: Report of working group on bacteria and phytoplankton. Archiv für Hydrobiologie Beiheft 43:31-69.

KIEBER, R.J., ZHOU, Z., and MOPPER, K. 1990. Formation of carbonyl compounds from UV-induced photodegradation of humic substances in natural waters: Fate of riverine carbon in the sea. Limnology and Oceanography 35:1503-1515.

KIRK, J.T.O. 1994. Light and photosynthesis in aquatic ecosystems. 2nd ed. Cambridge: Cambridge University Press.

KIRK, J.T.O., HARGREAVES, B.R., MORRIS, D.P., COFFIN, R.B., DAVID, B., FREDERICKSON, D., KARENTZ, D., LEAN, D.R., LESSER, M.P., MADRONICH, S., MORROW, J.H., NELSON, N.B., and SCULLY, N.M. 1994. Measurements of UV-B radiation in two freshwater lakes: An instrument intercomparison. Archiv für Hydrobiologie Beiheft 43:71-99.

KNUDSEN, B.M., LARSEN, N., MIKKELSEN, I.S., MORCETTE, J.J., BRAATHEN, G.O., KYRO, E., FAST, H., GERNANDT, H., KANZAWA, H., NAKANE, H., DOROKHOV, V., YUSHKOV, V., HANSEN, G., GIL, M., and SHERMAN, R.J. 1998. Ozone depletion in and below the Arctic vortex for 1997. Geophysical Research Letters 25:627-630.

LAURION, I., VINCENT, W.F., and LEAN, D.R.S. 1997. Underwater ultraviolet radiation: Development of spectral models for northern high latitude lakes. Photochemistry and Photobiology 65:107-114.

MANTOURA, R.F.C. 1987. Organic films at the halocline. Nature 328:579-580.

MARKAGER, S., and VINCENT, W.F. 2000. Spectral light attenuation and the absorption of UV and blue light in natural waters. Limnology and Oceanography 45:642-650.

McDONALD, R.W., SOLOMON, S.M., CRANSTON, R.E., WELCH, H.E., YUNKER, M.B., and GOBEIL, C. 1998. A sediment and organic carbon budget for the Canadian Beaufort Shelf. Marine Geology 144:255-273.

MORRIS, D.P., ZAGARESE, H., WILLIAMSON, C.E., BALSEIRO, E.G., HARGREAVES, B.R., MODENUTTI, B., MOELLER, R., and QUEIMALINOS, C. 1995. The attenuation of solar UV radiation in lakes and the role of dissolved organic carbon. Limnology and Oceanography 40:1381-1391.

NAIDU, A.S., BLANCHARD, A., KELLEY, J.J., GOERING, J.J., HAMEEDI, M.J., and BASKARAN, M. 1997. Heavy metals in the Chukchi Sea sediments as compared to selected circumarctic shelves. Marine Pollution Bulletin 35:260-269.

NEALE, P.J., CULLEN, J.J., and DAVIS, R.F. 1998. Inhibition of marine photosynthesis by ultraviolet radiation: Variable sensitivity of phytoplankton in the Weddell-Scotia Confluence during the austral spring. Limnology and Oceanography 43: 433-448.

OLSSON, K., and ANDERSON, L.G. 1997. Input and biogeochemical transformation of dissolved carbon in the Siberian shelf seas. Continental Shelf Research 17:819-833.

PEROVICH, D., ROESLER, C.S., and PEGAU, W.S. 1998. Variability in Arctic sea ice optical properties. Journal of Geophysical Research 103:1193-1208. 
PIENITZ, R., and VINCENT, W.F. 2000. Greater effects of climate change than ozone depletion on UV exposure in subarctic lakes. Nature 404:484-487.

QUESADA, A., and VINCENT, W.F. 1997. Strategies of adaptation by Antarctic cyanobacteria to ultraviolet radiation. European Journal of Phycology 32:335-342.

REX, M., HARRIS, N.R.P., VON DER GATHEN, P., LEHMANN, R., BRAATHEN, G.O., REIMER, E., BECK, A., CHIPPERFIELD, M.P., ALFIER, R., ALLAART, M., O'CONNOR, F., DIER, H., DOROKHOV, V., FAST, H., GIL, M., KYRO, E., LITNYSKA, Z., MIKKELSEN, I.S., MOLYNEAUX, M.G., NAKANE, H., NOTHOLT, J., RUMMUKAINEN, M., VIATTE, P., and WENGER, J. 1997. Prolonged stratospheric ozone loss in the 1995-96 Arctic winter. Nature 389:835-838.

SCHINDLER, D.W. 1998. A dim future for boreal waters and landscapes. BioScience 48:157- 164.

SCHINDLER, D.W., CURTIS, P.J., PARKER, B.R., and STAINTON, M.P. 1996. Consequences of climate warming and lake acidification for UV-B penetration in North American boreal lakes. Nature 379:705-708.

SCHLOSSER, P.D., BAUCH, R., FAIRBANKS, R.F., and BONISCH, G. 1994. Arctic riverine runoff: Mean residence time on the shelves and in the halocline. Deep-Sea Research I, 41:1053-1068.

SCULLY, N.M., and LEAN, D.R.S. 1994. The attenuation of ultraviolet radiation in temperate lakes. Archiv für Hydrobiologie Beiheft 43:135-144.

SETLOW, R.B. 1974. The wavelengths in sunlight effective in producing skin cancer: A theoretical analysis. Proceedings of the National Academy of Science 71:3363-3366.

SMITH, R.C., and BAKER, K.S. 1979. Penetration of UV-B and biologically effective dose-rates in natural waters. Photochemistry and Photobiology 29:311-323.

SMITH, R.C., WAN, Z., and BAKER, K.S. 1992. Ozone depletion in Antarctica: Modeling its effect on solar UV irradiance under clear sky conditions. Journal of Geophysical Research 97: 7383-7397.

STEELE, M., THOMAS, D., and ROTHROCK, D. 1996. A simple model study of the Arctic Ocean freshwater balance, 19791985. Journal of Geophysical Research 101:20,833-20,848.

VINCENT, W.F., and NEALE, P.J. 2000. Mechanisms of UV damage to aquatic organisms. In: de Mora, S.J., Demers, S., and Vernet, M., eds. The effects of UV radiation in the marine environment. Cambridge: Cambridge University Press. $149-176$.

VINCENT, W.F., LAURION, I., and PIENITZ, R. 1998. Arctic and Antarctic lakes as optical indicators of global change. Annals of Glaciology 27:671-676.

WESSEL, S., AOKI, S., WINKLER, P., WELLER, R., HERBER, A., GERNANDT, H., and SCHREMS, O. 1998. Tropospheric ozone depletion in polar regions: A comparison of observations in the Arctic and Antarctic. Tellus 50B:34-50.

WHEELER, P.A., WATKINS, J.M., and HANSING, R.L. 1997. Nutrients, organic carbon, and organic nitrogen in the upper water column of the Arctic Ocean: Implications for the sources of dissolved organic carbon. Deep-Sea Research II, 44: $1571-1592$.

WILLIAMSON, C.E., STEMBERGER, R.S., MORRIS, D.P., FROST, T.M., and PAULSEN, S.G. 1996. Ultraviolet radiation in North American lakes: Attenuation estimates from DOC measurements and implications for plankton communities. Limnology and Oceanography 41:1024-1034.

YUNKER, M.B., and MACDONALD, R.W. 1995. Composition and origins of polycyclic aromatic hydrocarbons in the Mackenzie River and on the Beaufort Sea shelf. Arctic 48:118-129.

ZEGOUAGH, Y., DERENNE, S., LARGEAU, C., BARDOUX, G., and MARIOTTI, A. 1998. Organic matter sources and early diagenetic alterations in Arctic surface sediments (Lena River Delta and Laptev Sea, eastern Siberia) II. Molecular and isotopic studies of hydrocarbons. Organic Geochemistry 28:571-583. 